Article

\title{
Impact of Pandemic Covid-19 on Higher Education-Indian Context
}

\author{
Pradip Kumar Das
}

How to cite this paper: Das, P. K. (2021). Impact of Pandemic Covid-19 on Higher Education-Indian Context. Universal Journal of Business and Management, 1(1), 13-21. DOI: 10.31586/ujbm.2021.010102. Retrieved from https://www.scipublications.com/journal/in-

dex.php/ujbm/article/view/44
Received: May 05, 2021

Accepted: June 15, 2021

Published: June 16, 2021

Copyright: (c) 2021 by the authors. Submitted for possible open access publication under the terms and conditions of the Creative Commons Attribution (CC BY) license (http://creativecommons.org/licenses /by/4.0/).
Department of Commerce, Jagannath Kishore College, Sidho- Kanho- Birsha University, Purulia, India

* Correspondence: pradip57.prl@rediffmail.com

\begin{abstract}
Education stratum of India as well as world are worst-hit by Covid-19 and has imposed lockdown originating deleterious effect on academic life. A sheer number of learners ceased moving educational institutions and all pedagogies halted in India. Catastrophe has behaved as a stimulant for the educational institutions to cultivate and choose for platforms with technologies which were previously noviced. Education sector has been challenging to weather the crux with alternative strategy and digitizing the challenges to hoover the menaces of the pandemic. Hypothesis of digital study has prognosis to impact the ventures of higher education for eon. Findings evince that despite digital learning is a nice adventure for little skills, varying illiberalities partake. Learners are crunched and academy also exclusively in unstable job. It has yet to be established the scope whereupon digital study would climactically cover for conventional study. Covid-19 conundrum has divulged prefacing dilemma and disparities clamoring synergetic attempt to contemplate even so pandemic's approach. This deliberate paper illuminates sparse impeccable education in India and has discussed the positive and negative impacts of Covid-19. The paper also contributes a methodical substantiation of the experience and lessons digested from the impact of the pandemic on the transitional education panorama, and the dissemination and acceptance of e-learning in education. To end, few suggestions along with policy recommendations have been made to meet didactics during the pandemic contingency.
\end{abstract}

Keywords: Covid-19; Education; Impact; Government of India; Pandemic

\section{Introduction}

Ubiquitous pandemic Covid-19 has impelled the human society to reason social distancing. Thus, every country's priority goal has become to alleviate the dissemination of the virus and alleviate its effects on the society in general, and the most vulnerable communities in particular. It has substantially disheveled the education sector, an overriding factor of a country's prosperity. Outbreak of Covid-19 has afflicted more than 120 cores of students and youths beyond the planet. In India, more than 32 cores of students have been implicated by various restrictions and nationwide lockdown. As per the UNESCO $[1,10]$ Report, about 14 cores of primary and 13 cores of secondary students are simulated which are mostly in India. Contemplating the situation, every country originates lockdown to isolate the contaminated people by keeping social distancing as advised by the WHO [2]. Lockdown pulverizes the stratagem of every student. Incipiently, the educators and the students were bewildered and unperceptive to address the environs of this sudden crisis that compelled closure of the academic activities. Although it is an exceptional situation, Covid-19 provides opportunities to come forward of the meticulous classroom teaching model to a paradigm shift of digital model. Thus, Covid fabricates many challenges and opportunities for the educational institutes to intensify their technological knowledge and infrastructure [3]. Lockdown has given sunbeam for teachers and students. Teachers assign work to students via different digital channels. However, 
numerous advanced educational institutions in India are not well-equipped with digital facilities to contend with metamorphosis from traditional education to online education system.

\section{Materials and Methods}

Data and information used for the study are mostly collected from various reports prepared by national and international agencies on Covid-19 pandemic. Information is also massed from various authentic websites. Journals and e-contents relating to impact of Covid-19 on educational systems are considered.

\section{Objectives}

The research paper focuses on the following objectives:

- To illumine various measures taken by the Government of India for education sector during this pandemic.

- To accentuate various positive and negative impacts of Covid-19 on education.

- To offer some constructive suggestions along with policy recommendations for perduring education during the pandemic situation.

\section{Results and Discussion}

\subsection{Initiatives of the Government on Education during Covid-19}

The Government of India has taken various protective measures to arrest the dissemination of pandemic Covid-19. The Union Government declared countrywide lockdown of all educational institutions on 16.03.2020. The Union Public Service Commission (UPSC) withheld the interview for the Civil Services Examination 2019 [4]. Similarly, most of the state governments and other educational boards withhold examinations due to the pandemic. Monitoring nationwide Janta-curfew on March 22, the Government of India executed lockdown from 25.03.2020 onwards in different stages and has been stretching lockdown periods sporadically adopting different strategies but educational institutions remained closed constantly. Almost all state government ministries have taken measures to corroborate not to perturb pedagogical scenario during the lockdown period and have counseled the institutions to hold all their classes by digital technology. Online learning is the best solution during this pandemic Covid-19 situation [5]. So, the digital India vision of the Government appears as an animated puppet for settling the extant catastrophe. The Ministry of Human Resource Development (MHRD) has made diverse plannings including online portals and educational channels for students to pursue learning. Students can also use popular social media tools for online teaching learning system. Digital endeavors of MHRD [6] for higher education during Covid-19 are as follows:

(i)Swayam is the national online education platform for higher education (under graduate, post graduate programs) in all subjects including engineering, humanities and social sciences, law and management courses. It is basically integrated with the traditional doctrine.

(ii)Swayam Prabha contains about 32 DTH TV channels transmitting educational contents and are available for watching across the country using DD Free Dish Set Top Box and Antenna. Channels incorporate higher education (undergraduate, postgraduate, engineering, vocational courses and teacher training) in arts, science, commerce, law, medicine, agriculture, etc.

(iii)e-PG Pathshala is for postgraduate students. Postgraduate students can retrieve this platform for e-books, online courses and didactic materials during this lockdown period. Students can ingress these provisions without internet for around-the-clock.

\subsection{Impact on Learning}


Transition to distance education has significant impact on faculty, students and programs. Many students prefer asynchronous courses while others synchronous. In general, students are strained. They are anxious about end-of-study and impact of distance education on their assessment. Depending on the circumstances, students prestidigitate distance learning, employment and nurturing aged dependants. Students and dependants lose employment and are occasionally unmoneyed. Students previously feeling invulnerable now feel vulnerable. Psychological problems may materialize, and many universities and colleges start provisions for psychological counseling. Situation is unhappy for international students. Vexation and inequity is usual for Asian faculty and North America students. Time adjustment is an enigma to them. Students hailing from some province in the Global South have insufficient digital infrastructure to back their distance learning. Many international students strive to find local accommodation after the campus and the dormitories are closed with arbitrarily. Restrictions on international travel and migration policies make many students troubled about their back to campus. Research projects are also saddened. Group projects are substituted by independent assignments. Some faculty and students develop distance counseling by less efficient means like video conferencing or messaging.

\subsection{Student and Faculty Inequities}

Inequities between students and faculty have been distinguished concerning home circumstances, access to technology and health issues. In this pandemic, although some students desire that they can work from home, they have home environment propitious to rich workplace conditions. But it is difficult to many international students and other poverty-stricken students. They need quietness but find it difficult to focus inaccessibility to library and study areas. There are also inequities from faculty perspective. Faculty in precarious employment is more vulnerable. Faculty doing international research modifies research arrangements due to potential inability to legally reenter the country. Race, ethnicity and family circumstances play a role in the ability of faculty to do their job.

\subsection{Positive Impact of Covid-19 on Education}

Educational institutions have accepted the conundrums of outbreak of Covid-19 and left no stone unturned to provide welfare works to the students. The following points may be considered as positive impacts.

i)Integrated course-Educational institutions have moved towards integrated learning model with the acceptance of digital technologies. Innovative approach of delivery and assessments have smiling reception approaching curriculum development. ii)Learning Management System (LMS)-Use of learning management systems has extended ample room for the companies developing and strengthening learning management systems $[7,8]$.

iii)Collaborative effort- Collaborative teaching and learning can take new shape. Collaborations can also eventuate among faculty globally to benefit each other $[7,8]$. Educators and learners enjoy opportunities to interact with peers across the world.

iv)Conference, seminar, etc.-Teleconferencing, virtual meetings, webinars, e-conferencing and seminars are basic eventualities of the pandemic.

v)Digital literacy-Students' digital literacy have well-developed pursuing their digital technology. They divvy soft copies of study materials and dissect apropos queries sprightly through e-mail, SMS, phone calls and maneuvering distinct multimedia.

vi)Open and Distance Learning (ODL)-During the pandemic situation, most of the students prefer ODL mode as it supports self-learning and tailor-learning according to their essentials. They can also regulate their time.

\subsection{Negative Impact of Covid-19 on Education}

Outbreak of Covid-19 has originated many negative impacts on education. Some of them are: 
i)Academic activity- Academic activities being hindered, lockdown fathers slump of academic session; thus, perceptibly debilitating the education sector. Although few skilled benevolent capable of leading in the house but others attaining naivety fizzles to do so.

ii) Extemporized intern teachers-Intern teachers are prepping for the metamorphosis from tete-a-tete learning to online learning. Most of the teachers are just conveying lectures on video platforms without any customized virtual learning belevedere.

iii)Employment opportunity-Students returning home following dismissal abroad have less probability to retrieve their jobs there due to travel restriction in the pandemic situation. Students recruited through campus interviews slip to join and young alumni also apprehend for pullback of career opportunities for the same reason. Recruitments being postponed, employment gradually shrinks. The Centre for Monitoring Indian Economy's guesstimates on unemployment ballooned from 8.4\% in mid-March to $23 \%$ in early April and the urban unemployment rate to $30.9 \%$ [9]. iv)Digital world-Poor students having insubstantial or no internet access hardly afford computer, laptop or supporting mobile phones in their homes. Online teachinglearning generate digital gap among students-rich or poor and urban or rural.

v)International education-Many Indian students studied abroad especially in gravely affected countries by the pandemic have no approach to evacuate these countries. Thus, a declension in the clamor for international higher education is contemplated.

vi)Fees payment-During lockdown most of the parents suffering from unemployment cannot afford fees for the time.

\subsection{Impediments to Online Studying}

- Impact of corona virus on education is ginormous. This pandemic impels alma mater to close precipitately divulging the massive discrepancy between destitute and affluent students.

- Outbreak of the virus interrupts learning for students in destitute areas internally. Families in financial distress cannot afford computers and Wi-Fi internet access.

- Vulnerable and impoverished students still bear the slam of academical pandemonium. Students from impoverished environs are ineluctably straggling.

- Spasmodic online study is conjectural for deserted students. Distance education requires infrastructure and sponsorship.

- Learners from impoverished areas attend charitable academy sustaining varying dilema like crumbling foundation, illiteracy, inadequate text, congestion, little instructors and vast retention rate. Divarications between institutions with fee and without fee apropos education quality. Accessing resources eventually discern the destiny of learner.

- Internet connection concerns, petty information and bare resources are key obstacles to online learning in impoverished areas.

- Students inadequately prepared to enter institutions of higher learning have probability of discontinuing studies.

- Girls are at high risk of health, progenitive exigencies, coerced female circumcision and budding marriage yielding their droppings.

- Disabled girls are impassable to information about their safeness from the virus. They are victims of problems rooted in age, disability and gender.

\subsection{Strategies for Education Sector In India}

Covid-19 has perceptibly fragmented the higher education sector. State governments across the country started halting institutions fleetingly as a measure to arrest the spread of the virus. With no expeditious nostrum to check the spate of virus, institutions closures bring short-term impact on the continuum of learning in India and breeds sweeping economic and civil ramifications. To uphold continuum of learning in educational 
institutions, digital learning solutions and LMS equip teachers administering online class. A multifront strategy helps captain the crisis and model a springy education system.

- DIKSHA platform across all states in India can be reinforced to confirm approachability of learning to the students.

- Comprehensive learning solutions for the most vulnerable and spurned can escalate the potency teaching-learning.

- Strategies are required to prepare the higher education sector for aborning market flows across the globe. Further, immediate measures can alleviate the sequel of the pandemic on apprenticeship schedules and research projects.

- Core issue at the national level is the seamless blend of technology in the Indian education system. It needs to establish quality control tool and quality baseline for online learning in India.

- Indian traditional knowledge systems in the areas of yoga, medicines, architecture, hydraulics and agriculture should be interlaced with prevailing education for the large community.

- An adaptable and impressive pedagogical technique for the endogenous development of new spirits cultivate skills to goad their credentials, fecundity, bloom and prosperity for universal blossoming of India.

UNESCO $[1,10]$ has made the following recommendations for online learning:[i] Examining the readiness and choosing the most relevant techniques; [ii]Confirming inclusion of the distance learning programmes; [3] Safeguarding data security; [iv]Emphasizing solutions to address psychosocial issues; [v]Planning the modules of the distance learning programmes; [vi]Extending help to teachers and parents on the use of digital tools; [vii]Incorporating appropriate approaches and governing the number of applications and platforms; [viii]Developing distance learning policies and monitoring students' learning process; [ix]Defining the duration of distance learning rooted in students' selfregulation skills; $[\mathrm{x}]$ Instituting communities and boosting connectivity.

\subsection{Are Digital Learning Platforms Enough for a Student?}

Currently, learning is not circumscribed to physical surroundings. Digital platforms have shaped our lives facile and have commissioned us to interact and manifest better. World today has become a classroom. India today with digital platforms helps learn from any place. But the question still remains-are these digital learning platforms sufficient for a student to learn? Even with all these supportive factors in digital learning, we are still indecisive in fingering an agreeable road over the conventional method of learning. A handful has adapted to the changing methods of learning; majority still stand by the primeval gauge and postulate that applying technology is specified to having PowerPoint Presentations in classrooms. In India, few institutions be blessed with their proficiency; but crux are oblivious.

On-campus education provides pragmatic learning. Learners for their first staying away from home meet people from different backgrounds and take their own decisions in the institute. But whether the students and their parents have willingness to pay high fees for online program is a debatable issue [11]. Strenuous energy can productively convey vigorous online learning involving concomitant online meeting among teachers and students.

\section{General Suggestions}

- India should elevate visionary strategies to corroborate that all learners from varied milieu must have equal access to learning during the pandemic.

- Immediate measures are required to lessen the effects of the pandemic on job offers, internship programs and research projects.

- Quality control tool and quality baseline for online learning must be developed in India heeding mushrooming of the digital learning platforms. 
- Indian traditional knowledge in varied fields is popular globally for its scientific innovations, values and benefits which can be blended with prevailing higher education system.

- Government and educational institutes should plan to pursue academic activities following guidelines of Covid-19.

- Access to technology is an instant poverty. So, digital culture and the requisite infrastructure must touch to the secluded and impecunious commune to precipitate the students for their study during the pandemics.

- Students' continuum to learn digitally must be clinched. State governments and private organizations should concoct ideas to address the issue of digital education.

- Government and stakeholders should address crucial issues like internet connectivity, safe learning place, teachers' competence, students' operation, lesson plans, etc. for disabled students and other vulnerable groups.

- Students' needs and technical profiles be carefully assessed in advance.

- E-learning is the only feasible substitute to oust tete-to-tete teaching. Live interactions between students and teachers are essential in online environments.

- Assessment of students' performance in online environments is an ultimatum to both instructors and students. Incorporation of alternative assessment methods and germane online is necessary.

- Digital literacy skills seem crucial for instructors but with this faculty training becomes critical need.

- Student's readiness to e-learning requires triumph and self-monitoring dexterity.

\subsection{Policy Recommendations}

Preventing the learning crisis from current catastrophe is crucial for the entire education community. A novel drive entitled 'Save our Future' will help dilate societal support for education now. Concerning this, decision-makers are incentivized to trail the following recommendations:

1.Restrain transmission of the virus and mold for reopening: The most significant step India can take to hasten the reopening of educational institutions is to suppress transmission of the virus for controlling national or local outbreaks.

i)Confirm the safety: A basic condition to reopening confirms secure return to personified places hypothesizing physical distancing and executing epidemiology benchmark as per guidelines of the UN and the savants.

ii)Design for extensive reopening: Most marginalized students should be incorporated in reopening strategies and adequate precautions required for disabled students.

iii)Heed to the views of all persons: Core of the decision-making process is consultation and corporate planning for reopening with communities and benefactors.

iv)Harmonize with key performers: Harmonizing with health agencies in planning reopening is recommended. Synergism with other civic policies for involvement of families suffering from the crisis is justly crucial. Dissemination with all education performers is essential for sound planning and reciprocating to meet the requirements of all learners and to enhance their persistence.

2.Safeguard education financing and synchronize: International community safeguards education financing. Increasing budgetary margin distinctly has become ineludible.

i)Invigorate domestic resourcing, scrimp education vital and address incompetence: Progressing amelioration and innovations should be belabored. Education and other social sector can use political clout for making tangible progress and ameliorating financial administration.

ii)Invigorate universal gaucheness: Mollifying, stalling and ameliorating liability for lower-middle-class countries should be fragment of the panacea to originate fiscal space for countries to finance in education from all stakeholders. 
iv)Vindicate true advancement accommodation: Health crisis has intensified the effect of meeting injustice on academic provision. Education should not be singled out.

3.Boost the buoyancy of academic policies: Boosting the buoyancy of academic policies accredits India to greet to burning issues of okayly reopening institutions and rests them to meet catastrophe.

i)Concentrate on equity and incorporation: Governments and their association confirm that education systems address the vulnerabilities and feminity in extremity. Deleterious feminity coupled with destituteness domestically should not derail girls and the neediest learners to conclude their study.

ii)Buttress credentials for crisis management: Potentialities bring in individual, and pedagogic strata to brave extremity. Transnational benefactors necessitate to appraise the potency of possible podium for quality education continuum.

iv)Uphold robust impetus and harmonization: National directorate assures light impact of climax on learners and academic communities. Close coordination tools swell the inputs of all benefactors including local civil society to serve the most marginalized.

4.Redefine education and boost positivity: Educational processes are amenable, unbigoted and comprehensive. We should grip the moment to unearth de novo to address the learning crisis and beget a look for viable approach.

i)Eyeballing on spouting academic losses and averting dropouts explicitly of marginalized groups;

ii)Proffer dexterity for curriculum vitae;

iii)Buttress teaching profession and educators' preparedness: Preceptor blossoming and professionalism corroborates their adequate qualification, remuneration and preparedness. Governments also invigorate morale boosters for educators, motivators and parents in the thriving practice of technology for educational process.

iv)Dilate the concept of right to education: Teachers and learners require free and publicly available technologies for teaching and learning. Governments should assist public pedagogical materials and initiate digital approach.

v)Uproot obstacles to congruence: Governments and development associates should collaborate to uproot technical hurdles. India necessitates planning not to dissipate students from the poorest pauperized domiciliary.

5.Boost details and superintending learning: Maneuvering the academic crisis requires incessant particulars at the student, teacher and institution levels. Attempts need help producing quality data to allow the constant counseling of the practice.

i)Invigorate the expression and versatility: A critical factor of springy education policy is its' amenability and also the competency to demonstrate new strategy of transmission.

\section{Conclusion}

Covid-19 has impacted immensely to the education sector of India. Although it has originated many troubles, multiple possibilities also sprang. Governments and benefactors of education have glimpsed the possibility of ODL by deploying different digital technologies to arrest the current crisis of Covid-19. India is not well-equipped to make digital education reach every inch of the nation. Unprivileged students tolerate for digital platforms. But universities and the Government are incessantly striving to fathom this issue. Digital technology should be given extremity to generate an conducive environment for millions of students. Educational institutions should rejuvenate their knowledge to face potential crisis. As the crisis fattens long, optimization of online platform is much-needed to validate the students not only concluding their degree but also preparing for the future 
ict-based environment. India should develop visionary strategies to confirm impregnable approach to learning during pandemic.

\section{Comment}

Trauma of the Covid-19 crisis on education has wizened the attainment of international education goals, and prodigiously traumatized the poor and most vulnerable. Government and the international community must adhere to principles and behave moralization so that besides students regaining their promised future, all benefactors also find their positions in triumphing. All-embracing health emergencies and lockdown have refreshed our cognizance of the value to society. Scenery is very unpredictable. Severances are not constrained to pandemics; but may also follow political, economic and environmental discombobulation. Education system necessitates planning heartily. True metamorphosis typically materializes in damascus road. This crisis has profound obstreperous reverberation on education. It is importunate, therefore, to mirror on the lessons learnt from the real sophistication so that higher education institution is more inclined to potential wing of the emergency e-learning.

\section{Implication of the Study}

The pandemic commands to rejuvenate the obligation to sustainability. Substantiating that all youths have opportunity to develop the knowledge, skills, attitudes and values permitting them to proffer to humanity is rudimentary of the umbrella programme and pedagogy's commitment to our ensuing civilization. Initiating and effectuating an comprehensive online education, however, might switch students' perspicacity. Present catastrophe has tested the waters to tackle mammoth derangements. It is now before us to fabricate its concoction as a springier mortality.

\section{Further Scope of the Study}

Modest degree of literature on teaching and learning under exigency are to be learnt. Distance learning may cause faculty to revamp core curriculum. Virtual realties are becoming more factual; but the question lies whether virtual substitutes to foster the identical level of learning and involvement of all students. Assessment, course assignment and probity are all necessary interrogations for investigation. Future indubitably demands further studies about quandary distance education. Well-designed, multi-institutional and extensive studies are the best technique for answering the interrogations. Future of oncampus-based study is resolute decisively, but the prevailing status is methodically nonviable and there is blossoming incredulity about the tomorrows. Inaccessibility of research labs and field sites, bottleneck to humankind and to outstay for preparation have perturbed e-learning research work.

\section{Acknowledgement:}

This paper is devoted to Almighty GOD who bestows HIS blessings in all walks of my life.

\section{Funding}

This research received no external funding.

\section{Data Availability Statement}

Already mentioned in appropriate sections.

\section{Conflicts of Interest}

No conflict of interest. 


\section{References}

[1] UNESCO, Covid-19 Educational Disruption and Response. Retrieved on WHO, 2020.

[2] WHO, “Corona Virus Disease (Covid-19) Dashboard”, https://covid19.who.int/ (assessed on May, 20, 2020).

[3] Jena Pravat K., Challenges and Opportunities Created by Covid-19 for ODL: A Case Study of IGNOU, International Journal for Innovative Research in Multidisciplinary Filed, 2020a, 6(5), 217-222.

[4] Wikipedia, “Covid-19 Pandemic in India", https://en.wikipedia.org/wiki/Education_in_India

[5] Jena Pravat K, Online Learning During Lockdown Period for Covid-19 in India, International Journal of Educational Research, 2020b, 9(5-8), 82-92.

[6] MHRD Notice (20 March, 2020). Covid-19 Stay Safe: Digital Initiatives, https://www.mohfw.gov.in/pdf/covid19.pdf (assessed May, 25, 2020).

[7] Misra Kamlesh, “Covid-19: 4 Negative Impacts and 4 Opportunities Created for Education”, , https://www.indiatoday.in/educationtoday/featurephila/story/covid-19-4-negativeimpactsand-4-opportunities-created-for-education-1677206-2020-05-12 (assessed May, 25, 2020).

[8] Misra Kamlesh, “Covid-19: 4 Negative Impacts and 4 Opportunities Created for Education", https://www.indiatoday.in/educationtoday/featurephilia/story/covid-19-4; negativeimpactsand-4-opportunities-created-for-education-1677206-2020-05-12 (assessed May, 25, 2020).

[9] Educationasia.in 2020, “The Impact of COVID-19 on Education and Education Sectors, Know Here", https://educationasia.in/article/the-impactof-covid-19-on-education-and education-sectors-knowhere (assessed May, 25, 2020).

[10] UNESCO. Covid-19 Educational Disruption and Response. Retrieved on WHO, 2020.

[11] Zimmerman, J. Will, "Students at Elite Colleges abide Online Education? Not likely", The Dallas Morning News, https://www.dallasnews.com/opinion/commentary/2020/04/09/will-students-at-elite-colleges-abide-online-education-notlikely/ (assessed Sept., 22, 2020). 